\section{Effect of Temperature on Seed Germination in Spinach (Spinacia oleracea)}

\author{
Jessica Chitwood, Ainong Shi ${ }^{1}$, Michael Evans, and Curt Rom \\ Department of Horticulture, 316 PTSC, University of Arkansas, Fayetteville, \\ AR 72701
}

Edward E. Gbur Jr.

Agricultural Statistics Laboratory, 101 Agricultural Annex, University of Arkansas, Fayetteville, AR 72701

Dennis Motes
Vegetable Research Center, University of Arkansas, Alma, AR 72921

Pengyin Chen

Department of Crop, Soil, and Environmental Sciences, 215 PTSC, University of Arkansas, Fayetteville, AR 72701

David Hensley

Department of Horticulture, 316 PTSC, University of Arkansas, Fayetteville, AR 72701

Additional index words. germplasm evaluation, breeding

\begin{abstract}
Breeding heat-tolerant spinach is an important project to meet the demand of increasing spinach production in heat conditions. Seed germination is the early stage to test, screen, and develop heat-tolerant spinach genotypes. The objective of this research was to determine temperature effect on the seed germination percentage and to select heat-tolerant spinach genotypes. A total of nine spinach genotypes were used in this research. The germination experiment was conducted using seven temperatures: 10,15 , $20,25,30,32$, and $35^{\circ} \mathrm{C}$ under growth chambers. The temperature trials were conducted using completely randomized design (CRD) with three replicates. Spinach seed germination percentage varied among the nine spinach genotypes under the seven temperatures, indicating that genetic variation for heat tolerance existed in the nine spinach genotypes. 'Donkey', 'Marabu', and 'Raccoon' showed higher seed germination percentage with over $70 \%$ at 30 and $32{ }^{\circ} \mathrm{C}$, indicating the three spinach genotypes had heat tolerance for germination. However, all spinach genotypes except 'Ozarka II' dropped their germination percentages sharply to less than $30 \%$; 'Ozarka II' had $63 \%$ germination under $35{ }^{\circ} \mathrm{C}$, indicating it is a good source of heat tolerance for seed germination. The higher germination percentages above $30{ }^{\circ} \mathrm{C}$ of 'Ozarka II', 'Donkey', 'Marabu', and 'Raccoon' may indicate their potential as donors of heat-tolerant traits in spinach breeding program.
\end{abstract}

The economic value of spinach (Spinacia oleracea L.) continues to grow in the United States as well as globally due to its high nutritive content. Spinach production has been valued over $\$ 250$ million in the United States in 2014 (USDA, 2015). Spinach is grown for fresh market, freezing, and canning; and $90 \%$ of the spinach grown in the United States is for fresh market (Naeve, 2015). California, Arizona, Texas, and New Jersey grow up to $98 \%$ of the commercial fresh market spinach (Naeve, 2015). Nearly half of California's spinach is grown in Monterey County, and although spinach can be grown there nearly year-round, production

Received for publication 3 Oct. 2016. Accepted for publication 20 Oct. 2016.

${ }^{1}$ Corresponding author. E-mail: ashi@uark.edu. is limited to the regions and seasons that meet the temperature requirements of spinach (Koike et al., 2011). In Arizona and Texas, production mainly takes place in the winters (CFAITC, 2014).

Spinach is a cool-season vegetable and depending on climate, typically grown in the early spring or late fall when the danger of higher temperatures is not as high (Anderson, 2014). Prior experiments have shown that spinach seeds will germinate in soil temperatures from 5 to $30{ }^{\circ} \mathrm{C}$ with germination percentages highest at $20^{\circ} \mathrm{C}$ and dropping abruptly between 25 and $30^{\circ} \mathrm{C}$ (Atherton and Farooque, 1983). Spinach seed germination has been reported to cease entirely at $35{ }^{\circ} \mathrm{C}$ (Leskovar and Esensee, 1999). Substantial seedling root development requires temperatures above $18.9^{\circ} \mathrm{C}$, and top growth will be limited at temperatures below $12.3{ }^{\circ} \mathrm{C}$ and above $23.3{ }^{\circ} \mathrm{C}$ (Wilcox and Pfeiffer, 1990). Studies have been done on the heat-shock response of spinach, both with whole plants and detached leaf tissue. It has been reported that after being exposed to heat shock (35$50{ }^{\circ} \mathrm{C}$ ) for $30 \mathrm{~min}, \mathrm{CO}_{2}$ assimilation decreases and pigment proteins in thylakoid membranes aggregate, slowing down the plant's ability to photosynthesize (Tang et al., 2007). In addition, the first heat-shock proteins in spinach leaf tissue are induced when the temperature reaches $28^{\circ} \mathrm{C}$ and a full range of heat-shock proteins are produced at $36^{\circ} \mathrm{C}$ (Somers et al., 1989). If a spinach genotype has a high germination percentage in high temperature such as $35^{\circ} \mathrm{C}$, it should be a heat-tolerant spinach in germination stage.

Rapid and uniform germination is also necessary for efficient crop production, both in field and greenhouse practices. Although it has been reported that seed treatments may be effective for increasing germination of spinach at higher temperatures (Katzman et al., 2001), managing this trait via selecting heattolerant genotypes is a more manageable practice for spinach producers.

Germination under heat stress may also play a significant role in selecting heattolerant genotypes. Historically, mass selection was the primary method for developing genotypes, with hybrid breeding becoming popular in recent years, but all are based on field testing (Morelock and Correll, 2008). Although field testing is necessary in many cases, there are numerous environmental effects that contribute to germination performance beyond that of temperature. Therefore, it may be useful to reduce the number of genotypes planted by preliminary testing, improving the statistical approach to reduce error and estimate genotype by environment interaction. Using germination as this pretest has been successful in other crops, such as sorghum (Tiryaki and Andrews, 2001), and would allow quicker and more efficient selections to be made.

The objectives of this study are to determine how temperature affects spinach seed germination and evaluate potential genetic variation for germinating under heat stress.

\section{Materials and Methods}

Nine spinach genotypes were used in this study. 'Donkey', 'Marabu', 'Tyee', 'Samish', and 'Raccoon' are commercially available genotypes (Snow Seed Company, 2013, http:// snowseedcompany.com/). These genotypes were selected because of their popularity and heat-tolerant qualities. 'Donkey', 'Marabu', and 'Tyee' have been marketed as being heat tolerant or good for summer spinach production (Swallow Tail Garden Seeds, 2015 ). 'Samish' and 'Raccoon' are not described as heat tolerant and were chosen for comparison. Four genotypes from the University of Arkansas spinach breeding program, 'Ozarka II', 'Fallgreen', F88-310, and F88-354 (Brandenberger et al., 1991) were also used. 'Ozarka II' and 'Fallgreen' are genotypes that were released in 1984 and 1987, respectively, whereas F88-310 and 
F88-354 are breeding lines from the University of Arkansas spinach breeding program (Morelock and Correll, 2008). Most of the seeds from these genotypes were harvested in 2008 and stored at $-20^{\circ} \mathrm{C}$. These genotypes were selected because of their frequent use in past spinach production in Arkansas, and also because these are advanced lines with very high white rust (Correll et al., 2010) and will likely be used as parents by the spinach breeding program.
The experiment was conducted in growth chambers at the Harry R. Rosen Alternative Pest Control Center of University of Arkansas. There were seven temperature treatments: 10 , $15,20,25,30,32$, and $35^{\circ} \mathrm{C}$. The previously reported optimum for spinach germination is $20{ }^{\circ} \mathrm{C}$ (Atherton and Farooque, 1983); therefore two temperatures below the optimum, 10 and $15{ }^{\circ} \mathrm{C}$, were used. Previous studies have shown that germination is inhibited at $30{ }^{\circ} \mathrm{C}$ (Atherton and Farooque, 1983; Katzman et al.,

Table 1. Germination percentages of nine spinach genotypes at each of the seven temperatures.

\begin{tabular}{lclllllll}
\hline Genotype & \multicolumn{1}{c}{$10^{\circ} \mathrm{C}$} & \multicolumn{1}{c}{$15^{\circ} \mathrm{C}$} & \multicolumn{1}{c}{$20^{\circ} \mathrm{C}$} & \multicolumn{1}{c}{$25^{\circ} \mathrm{C}$} & $30^{\circ} \mathrm{C}$ & $32{ }^{\circ} \mathrm{C}$ & $35^{\circ} \mathrm{C}$ & LSM $^{\mathrm{y}}$ \\
\hline Ozarka II & $68.7 \mathrm{~B}$ & $90.7 \mathrm{BC}$ & $87.3 \mathrm{ABC}$ & $81.7 \mathrm{BCD}$ & $78.0 \mathrm{~A}$ & $75.0 \mathrm{AB}$ & $63.0 \mathrm{~A}$ & $77.8 \mathrm{~A}$ \\
Fallgreen & $56.7 \mathrm{C}$ & $68.7 \mathrm{E}$ & $74.3 \mathrm{BC}$ & $66.7 \mathrm{E}$ & $33.3 \mathrm{C}$ & $34.0 \mathrm{E}$ & $27.3 \mathrm{~B}$ & $51.6 \mathrm{~B}$ \\
F88-310 & $91.0 \mathrm{~A}$ & $94.7 \mathrm{ABC}$ & $68.0 \mathrm{C}$ & $76.0 \mathrm{CD}$ & $80.0 \mathrm{~A}$ & $54.3 \mathrm{CD}$ & $23.3 \mathrm{BC}$ & $69.6 \mathrm{~A}$ \\
Donkey & $96.0 \mathrm{~A}$ & $92.7 \mathrm{ABC}$ & $86.7 \mathrm{ABC}$ & $93.3 \mathrm{~A}$ & $73.3 \mathrm{~A}$ & $81.3 \mathrm{~A}$ & $20.7 \mathrm{BCD}$ & $77.7 \mathrm{~A}$ \\
Tyee & $96.0 \mathrm{~A}$ & $96.7 \mathrm{AB}$ & $89.3 \mathrm{AB}$ & $74.7 \mathrm{DE}$ & $44.0 \mathrm{C}$ & $34.7 \mathrm{E}$ & $19.3 \mathrm{BCDE}$ & $65.0 \mathrm{AB}$ \\
Marabu & $72.7 \mathrm{~B}$ & $90.0 \mathrm{C}$ & $80.0 \mathrm{ABC}$ & $86.7 \mathrm{AB}$ & $70.7 \mathrm{AB}$ & $78.0 \mathrm{~A}$ & $13.3 \mathrm{CDEF}$ & $70.2 \mathrm{~A}$ \\
F88-354 & $66.7 \mathrm{~B}$ & $97.7 \mathrm{~A}$ & $96.7 \mathrm{~A}$ & $83.3 \mathrm{BC}$ & $70.7 \mathrm{AB}$ & $49.3 \mathrm{DE}$ & $9.7 \mathrm{DEF}$ & $67.7 \mathrm{~A}$ \\
Raccoon & $94.0 \mathrm{~A}$ & $98.0 \mathrm{~A}$ & $84.0 \mathrm{ABC}$ & $88.7 \mathrm{AB}$ & $84.0 \mathrm{~A}$ & $69.3 \mathrm{ABC}$ & $8.7 \mathrm{EF}$ & $75.2 \mathrm{~A}$ \\
Samish & $91.3 \mathrm{~A}$ & $80.0 \mathrm{D}$ & $85.3 \mathrm{ABC}$ & $82.0 \mathrm{BCD}$ & $58.7 \mathrm{~B}$ & $58.7 \mathrm{BCD}$ & $6.7 \mathrm{~F}$ & $66.1 \mathrm{AB}$ \\
\hline
\end{tabular}

${ }^{\mathrm{z}}$ Significant test of seed germination percentages of the nine spinach genotypes across each temperature. The capital letters represent the statistical significance at $P=0.01$ level for each temperature listed in the column of the table.

${ }^{\mathrm{y}}$ LSM signifies the least squares mean for each of nine spinach genotypes, estimated from JMP Genomics.

2001) and suppressed altogether at $35{ }^{\circ} \mathrm{C}$ (Leskovar and Esensee, 1999). Therefore, 30,32 , and $35{ }^{\circ} \mathrm{C}$ were chosen as the heat-stress treatments.

Seeds were surface sterilized before the germination tests following methods of Sauer and Burroughs (1986). Seeds were first soaked for $1 \mathrm{~h}$ in distilled water, then rinsed for $30 \mathrm{~s}$ in $100 \%$ ethanol. Next, seeds were soaked in a $2 \% \mathrm{NaOCl}$ solution for $10 \mathrm{~min}$, and finally rinsed with autoclaved water three times.

The germination tests followed the procedures listed by the Association of Official Seed Analysts (AOSA, 1993). For each genotype, 50 seeds were placed on top of two sheets of blotter paper in $9-\mathrm{cm}$ petri dishes. Dishes were premoistened with $2 \mathrm{~mL}$ autoclaved water (Heydecker and Orphanos, 1968) and placed into zip-sealing bags to prevent water loss. Seeds were allowed to germinate at the designated temperature for $21 \mathrm{~d}$ (AOSA, 1993). Germinated seeds were counted and removed on 7-d intervals beginning the 7 th day after sowing. Seeds were considered germinated when $1 \mathrm{~mm}$ of the radicle had protruded through the seed coat. The experimental design was $\mathrm{CRD}$ with three replicates.

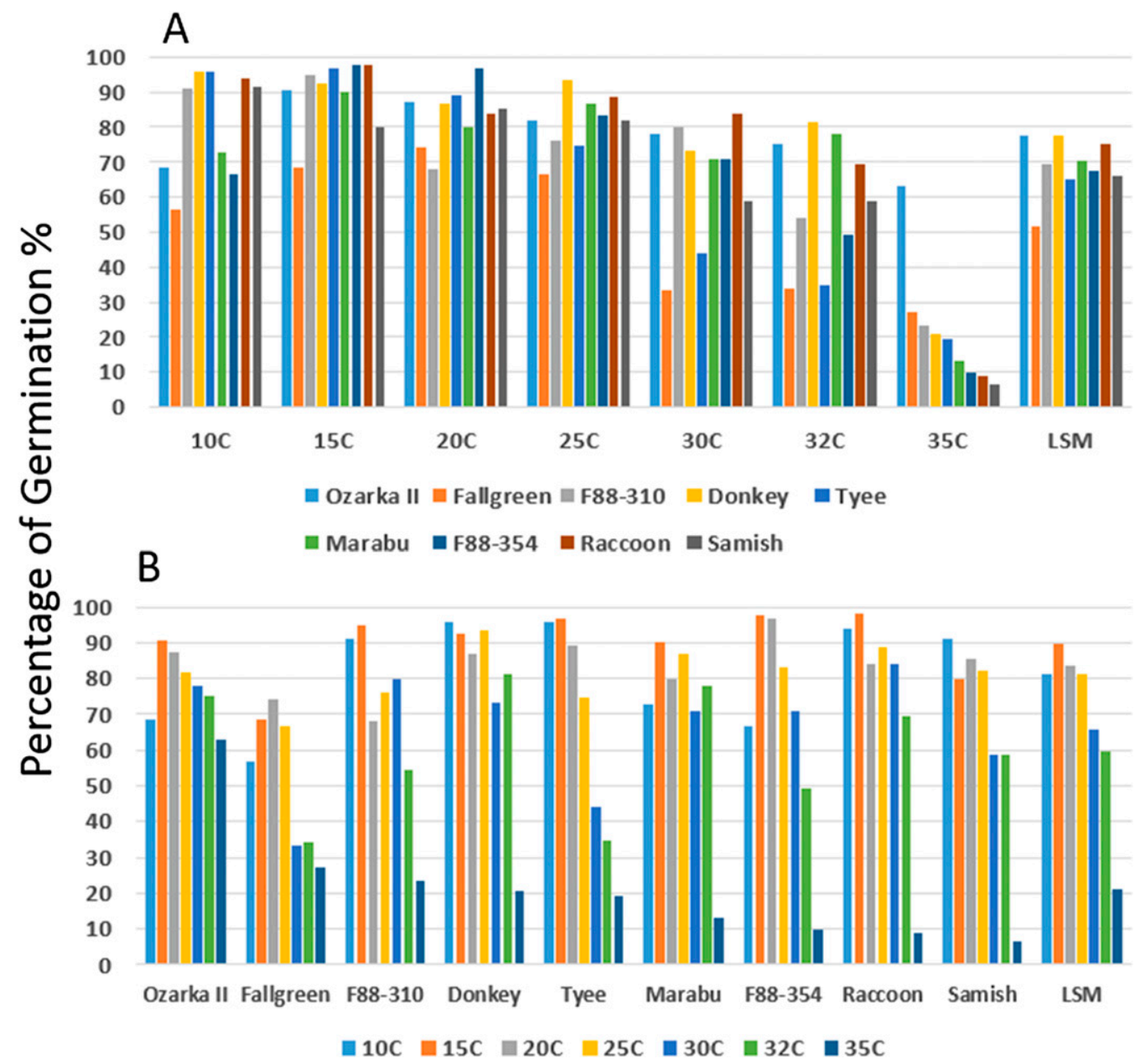

Fig. 1. Germination percentages of nine spinach genotypes at seven temperatures: (A) grouped by seven temperatures plus the LSM of each spinach genotype and (B) grouped by each of the nine spinach genotypes plus the LSM of each temperature. LSM = least squares mean of germination percentage calculating either from seven temperatures (A) or from nine spinach genotypes (B) by JMP Genomics and the figure was drawn using Microsoft Excel. In A, the spinach order is 'Ozark II', 'Fallgreen', F88-310, 'Donkey', 'Tyee', 'Marabu', F88-354, 'Raccoon', and 'Samish' and in B, the temperature order is 10, 15, 20, 25, 30, 32, and $35^{\circ} \mathrm{C}$. 
Germination percentages were calculated and analyzed with Microsoft Excel and JMP Genomics (SAS, 2014). Microsoft Excel 2013 was used for data organization and drawing plots to display the germination percentage by temperature. Analysis of variance in JMP was used for statistical analysis. The least squares mean was calculated for each genotype by temperature as well as for each temperature by genotype. The student's $t$ test is used to analyze the significant differences of the data.

\section{Results and Discussion}

Variation was observed among the nine genotypes for germination under the seven temperatures tested (Table 1; Fig. 1). 'Donkey', 'Tyee', F88-310, 'Raccoon', and 'Samish' had the highest germination percentages at $10{ }^{\circ} \mathrm{C}$; 'Ozarka II', 'Marabu', and F88-354 had intermediate germination percentages; and 'Fallgreen' had the lowest germination percentage of the nine genotypes. At $15{ }^{\circ} \mathrm{C}$, 'Raccoon' and F88-354 had the highest germination percentages ( $98 \%$ and $97.7 \%$, respectively), although they were not significantly different from F88-310, 'Donkey', and 'Tyee' with $92 \%$ to $96 \%$. Seven of the nine genotypes had similar germination percentages $(80 \%$ to $89 \%)$ at $20{ }^{\circ} \mathrm{C}$, which was expected because $20^{\circ} \mathrm{C}$ is the optimal temperature for spinach seed germination (Atherton and Farooque, 1983). At $25^{\circ} \mathrm{C}$, 'Donkey', 'Marabu', and 'Raccoon' had the highest germination percentages between $86 \%$ and 93\%. 'Ozarka II', F88-354, and 'Samish' made up the next group from $83 \%$ to $81 \%$. F88-310 followed with $76 \%$, then 'Tyee' with $74 \%$, and finally 'Fallgreen' with the lowest of $66 \%$.

Germination percentages remained unexpectedly high at $30{ }^{\circ} \mathrm{C}$ except for 'Fall Green', 'Tyee', and 'Samish'. Although seed priming has been reported to result in higher germination percentages for spinach seeds germinated at $30{ }^{\circ} \mathrm{C}$ (Katzman et al., 2001), studies have shown that germination inhibition begins at temperatures exceeding $20^{\circ} \mathrm{C}$, and germination is totally suppressed by $35{ }^{\circ} \mathrm{C}$ (Leskovar and Esensee, 1999). We observed that 'Raccoon' and F88-310 had above $80 \%$ germination, and 'Ozarka II', 'Donkey', 'Marabu', and F88-354 had above $70 \%$ germination at $25^{\circ} \mathrm{C}$. Further, at $32^{\circ} \mathrm{C}$, 'Donkey', 'Marabu', and 'Ozarka II' had germination percentages remaining above $75 \%$. Finally, all genotypes except 'Ozarka II' had reduced germination percentage to less than $30 \%$ at $35^{\circ} \mathrm{C}$, while 'Ozarka II' had high germination with $63 \%$ (Table 1; Fig. 1).

Variation among genotypes may result from several factors including the production of heat-shock proteins (Hum-Musser et al., 1999). Organisms produce heat-shock proteins to respond to heat stress (Somers et al., 1989). These proteins function as molecular chaperones and may be crucial for cell survival under heat stress (Waters et al., 1996). Hum-Musser et al. (1999) evaluated heat-tolerant proteins in seeds germinated under heat stress for several genotypes, including

Temperature at $35^{\circ} \mathrm{C}$

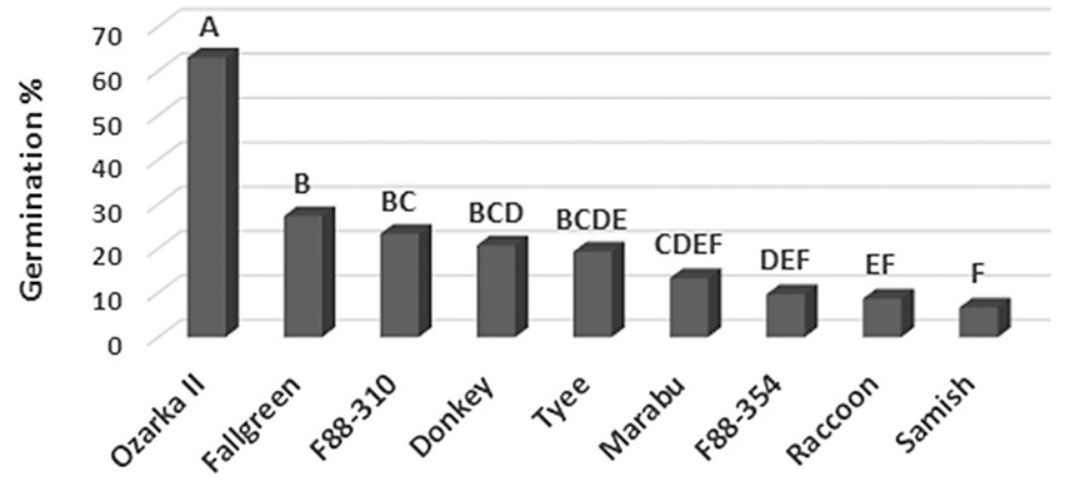

Fig. 2. Germination percentage of spinach genotypes at $35^{\circ} \mathrm{C}$. The letters $\mathrm{A}, \mathrm{B}, \mathrm{BC}, \mathrm{BCD}, \mathrm{BCDE}, \mathrm{CDEF}$, $\mathrm{DEF}, \mathrm{EF}$, and F represent the Student's $t$ test at $P=0.01$ level by JMP Genomics and the figure was drawn using Microsoft Excel.

the University of Arkansas genotype Fallgreen, and found a higher accumulation of heat-shock proteins in the genotypes with higher germination percentages under heat stress. 'Ozarka II' may have the ability to produce greater amounts of heat-shock proteins than the other genotypes we tested.

Comparing 'Donkey', 'Marabu', and 'Tyee', genotypes marketed as heat tolerant, to 'Raccoon' and 'Samish', genotypes not marketed as heat tolerant, at $35^{\circ} \mathrm{C}$ does not offer a clear illustration of accuracy in these heat tolerance claims (Table 1; Fig. 1). 'Donkey', 'Tyee', and 'Marabu' were expected to maintain higher germination percentages at higher temperatures, but 'Tyee' had the lowest germination percentage at 30 and $32{ }^{\circ} \mathrm{C}$ of the five genotypes. 'Raccoon' had the highest germination percentage of $84 \%$ at $30{ }^{\circ} \mathrm{C}$. Only at $35^{\circ} \mathrm{C}$, 'Donkey', 'Marabu', and 'Tyee' as a group have higher germination percentages than 'Raccoon' and 'Samish' (Table 1; Fig. 1).

University of Arkansas germplasm has been incorporated into many genotypes over the years (Morelock and Correll, 2008), and several of these have been used in studies of spinach seed germination under heat stress (Hum-Musser et al., 1999; Leskovar and Esensee, 1999). Interestingly, the University of Arkansas genotypes seem to be among the more heat-tolerant genotypes. In this study, three of the four spinach genotypes from the University of Arkansas had higher germination percentages than the commercially available genotypes (Fig. 2). This may be the result of spinach selection under heat conditions in Arkansas, where spinach breeding lines are planted in the early fall and selected throughout the winter and spring in Alma, AR. Average high temperatures for Alma between August and October range from 24 to $34{ }^{\circ} \mathrm{C}$ (U.S. Climate Data, 2015), and recurrent selection of lines that are able to germinate and tolerate these or higher temperatures may have resulted in improved heat tolerance among University of Arkansas spinach germplasm. Recurrent selection has been shown to be a successful strategy in breeding for heat tolerance in wheat (Machado et al., 2010) and the unintended but nevertheless present selection pressure for heat tolerance in University of Arkansas spinach lines may result in future releases of heat-tolerant genotypes.

\section{Conclusions}

The optimum temperature for spinach seed germination was between 15 and $20{ }^{\circ} \mathrm{C}$ from this study. Above $20^{\circ} \mathrm{C}$, germination percentages decrease, with a sharp drop at $35^{\circ} \mathrm{C}$. Variation among spinach genotypes was observed, suggesting that breeding for heat tolerance is a possibility. The University of Arkansas genotype Ozarka II was more heat tolerant than the other genotypes tested and may be used as a donor of heat tolerance in the University of Arkansas spinach breeding program.

\section{Literature Cited}

Anderson, C.R. 2014. Home Gardening series: Spinach. FSA 6077. University of Arkansas Division of Agriculture. 13 Jan. 2014. <http:// www.uaex.edu/Other_Areas/publications/PDF/ FSA-6077.pdf>

Association of Official Seed Analysts (AOSA) 1993. Rules for testing seeds. Assn. Offic. Seed Analysts, Bozeman, MT.

Atherton, J.G. and A.M. Farooque. 1983. High temperature and germination in spinach. I. The role of the pericarp. Sci. Hort. 19:25-32.

Brandenberger, L.P., J.C. Correll, T.E. Morelock, and R.W. McNew. 1991. Characterization of resistance of spinach to white rust (Albugooccidentalis) and downy mildew (Peronospora farinosa $\mathrm{f}$. $\mathrm{sp}$. spinaciae). Phytopathology 84:431-437.

California Foundation for Agriculture in the Classroom (CFAITC). 2014. Commodity fact sheet: Spinach. CFAITC, Sacramento, CA.

Correll, J.C., B.H. Bluhm, C. Feng, K. Lamour, L.J. du Toit, and S.T. Koike. 2010. Spinach: Better management of downy mildew and white rust through genetics. Eur. J. Plant Pathol. 129:193205.

Heydecker, W. and P.I. Orphanos. 1968. The effect of excess moisture on the germination of Spinacia oleracea L. Planta 83:237-247.

Hum-Musser, S.M., T.E. Morelock, and J.B Murphy. 1999. Relation of heat-shock proteins 
to thermotolerance during spinach seed germination. Horticultural studies. Ark. Agr. Expt. Sta. Res. Ser. 466:103-105.

Katzman, L., A. Taylor, and R. Langhans. 2001. Seed enhancements to improve spinach germination. HortScience 36:979-981.

Koike, S., M. Cahn, M. Cantwell, S. Fennimore, M. Lestrange, E. Natwick, R. Smith, and E. Takele. 2011. Spinach production in California. Univ. California Agr. Natural Resources. Publ. 7212.

Leskovar, D. and V. Esensee. 1999. Pericarp, leachate, and carbohydrate involvement in thermoinhibition of germinating spinach seeds. J. Amer. Soc. Hort. Sci. 124:301-306.

Machado, J., M. Souza, D. Oliveira, A. Cargnin, A. Pimentel, and J. Assis. 2010. Recurrent selection as breeding strategy for heat tolerance in wheat. Crop Breed. Appl. Biotechnol. 10:9-15.

Morelock, T.E. and J.C. Correll. 2008. Spinach, p. 189-218. In: J. Prohens and F. Nuez (eds.).
Vegetables I: Asteraceae, Brassicaceae, Chenopodiaceae, and Cucurbitaceae. Springer, New York, NY.

Naeve, L. 2015. Spinach. Agr. Mktg. Resource Ctr. 22 June 2016. <http://www.agmrc.org/commoditiesproducts/vegetables/spinach/>.

Sauer, D.B. and R. Burroughs. 1986. Disinfection of seed surfaces with sodium hypochlorite. Phytopathology 76:745-749.

Snow Seed Company. 2013. Products list: Spinach. 12 Nov. 2013. <http://www.snowseedco.com/ vegetables/spinach/>.

Somers, D., W.R. Cummins, and W.G. Filion. 1989. Characterization of the heat-shock response in spinach (Spinacia oleracea L.). Biochem. Cell Biol. 67:113-120.

Swallow Tail Garden Seeds. 2015. Spinach seeds. 22 June 2016. <http://www.swallowtailgardenseeds. com/veggies/spinach.html $>$.

Tang, Y., X. Wen, Q. Lu, Z. Yang, Z. Cheng, and C. Lu. 2007. Heat stress induces and aggregation of the light-harvesting complex of photosystem II in spinach plants. Plant Physiol. 143:629-638.

Tiryaki, I. and D. Andrews. 2001. Germination and seedling cold tolerance in sorghum: I. Evaluation of rapid screening methods. Agron. J. 93:1386-1391.

U.S. Climate Data. 2015. Climate Fort SmithArkansas. 22 June 2016. <http://www.usclimatedata.com/climate/fort-smith/arkansas/unitedstates/usar0197>.

U.S. Department of Agriculture (USDA), National Agriculture Statistics Service. 2015. Vegetables 2014 Summary. U.S. Dept. Agr. Natl. Agr. Stat. Serv., Washington, DC.

Waters, E.R., J.L. Garrett, and E. Vierling. 1996. Evolution, structure, and function of the small heat-shock proteins in plants. J. Expt. Bot. 47:325-338.

Wilcox, G.E. and C.L. Pfeiffer. 1990. Temperature effect on seed germination, seedling root development, and growth of several vegetables. J. Plant Nutr. 13(11):1393-1403. 